\title{
C-type natriuretic peptide is a bifurcation factor for sensory
} neurons

\author{
Hannes Schmidt*1, Agne Stonkute ${ }^{1}$, René Jüttner ${ }^{1}$, Doris Koesling ${ }^{2}$, \\ Andreas Friebe ${ }^{2}$, Robert Feil ${ }^{3}$, Franz Hofmann ${ }^{4}$ and Fritz G Rathjen ${ }^{1}$
}

\author{
Address: ${ }^{1}$ Max Delbrück Center for Molecular Medicine, Robert-Rössle-Str. 10, 13125 Berlin, Germany, ${ }^{2}$ Institute for Pharmacology and \\ Toxicology, Ruhr University Bochum, 44780 Bochum, Germany, ${ }^{3}$ Institute for Biochemistry, Erhard Karls University Tübingen, 72076 Tübingen, \\ Germany and ${ }^{4}$ Institute for Pharmacology and Toxicology, Technical University Munich, 80802 Munich, Germany \\ Email: Hannes Schmidt* - hannes.schmidt@mdc-berlin.de \\ * Corresponding author
}

from 4th International Conference of cGMP Generators, Effectors and Therapeutic Implications

Regensburg, Germany. 19-21 June 2009

Published: II August 2009

BMC Pharmacology 2009, 9(Suppl I):P64 doi:I0.I I86/I47I-22 I0-9-SI-P64

This abstract is available from: http://www.biomedcentral.com/I47I-22 I0/9/SI/P64

(c) 2009 Schmidt et al; licensee BioMed Central Ltd.

\section{Background}

Axonal branching is a key mechanism for the development of neuronal circuitry providing the physical basis for the distribution and integration of information. Two modes of axonal branch formation can be distinguished: 1) growth cone bifurcation and 2) interstitial branching of collaterals both of which may be studied in axon projections of dorsal root ganglion (DRG) neurons into the spinal cord. Our previous studies of sensory axon trajectories identified a cGMP signaling cascade comprising the receptor guanylyl cyclase natriuretic peptide receptor 2 (Npr2) and the cGMP-dependent protein kinase I (cGKI) critically involved in axonal bifurcation of sensory axons at the dorsal root entry zone (DREZ) of the spinal cord. $[1,2]$.

\section{Results}

Analyzing the mechanism of Npr2 activation in DRG we found that C-type natriuretic peptide (CNP) is the only natriuretic peptide expressed in the embryonic spinal cord. Biochemical investigations revealed a Npr2-dependent increase in cGMP levels in DRG upon CNP stimulation. The generation of a CNP-knockout mouse where CNP is replaced by a lacZ expression cassette allowed the monitoring of CNP expression. Consistent with a function as an instructive signal for the ingrowth of sensory axons CNP starts to be expressed at E9 in the spinal cord forming a rostro-caudal gradient as development proceeds. In transverse sections CNP was initially detected in the entire dorsal quarter of the cord but became concentrated within the dorso-medial parts of the cord sparing the roof plate at more advanced stages. Comparison of the phenotype detected in the CNP mutant mouse with those lacking Npr2-activity or cGKI revealed a complete overlap in all aspects analyzed indicating that these three components act in a cascade. CNP-deficient mice displayed the pathfinding error, a reduced size of the dorsal funiculus, as well as the failure of sensory axon bifurcation. Furthermore, identical errors were found in the CNPlbab mouse which contains a single point mutation in the CNP gene. At a functional level, the distorted axonal branching is accompanied by reduced synaptic input, as revealed by patch clamp recordings of second-order neurons in the dorsal horn of the spinal cord of CNP mutants [3].

\section{Conclusion}

Hence, our data demonstrate that a cGMP signaling cascade including CNP, Npr2, and cGKI is essential for axonal bifurcation at the DREZ and influences neuronal connectivity in the dorsal spinal cord.

\section{Acknowledgements}

This work was supported by the Deutsche Forschungsgemeinschaft (SFB 665). 


\section{References}

I. Schmidt H, Werner M, Heppenstall PA, Henning M, More MI, Kuhbandner S, Lewin GR, Hofmann F, Feil R, Rathjen FG: cGMP-mediated signaling via cGKlalpha is required for the guidance and connectivity of sensory axons. / Cell Biol 2002, 1 59:489-498.

2. Schmidt H, Stonkute A, Jüttner R, Schäffer S, Buttgereit J, Feil R, Hofmann F, Rathjen FG: The receptor guanylyl cyclase Npr2 is essential for sensory axon bifurcation within the spinal cord. J Cell Biol 2007, I 79:33I-340.

3. Schmidt $H$, Stonkute $A$, Jüttner R, Koesling $D$, Friebe $A$, Rathjen $F G$ : C-type natriuretic peptide (CNP) is a bifurcation factor for sensory neurons. in press.

Publish with Bio Med Central and every scientist can read your work free of charge

"BioMed Central will be the most significant development for disseminating the results of biomedical research in our lifetime."

Sir Paul Nurse, Cancer Research UK

Your research papers will be:

- available free of charge to the entire biomedical community

- peer reviewed and published immediately upon acceptance

- cited in PubMed and archived on PubMed Central

- yours - you keep the copyright

Submit your manuscript here:

http://www.biomedcentral.com/info/publishing_adv.asp 